\title{
Anticonvulsant, Anxiolytic, and Sedative Activities of Verbena officinalis
}

\author{
Abdul Waheed Khan ${ }^{1}$, Arif-ullah Khan ${ }^{1 *}$ and Touqeer Ahmed ${ }^{2}$ \\ ' Department of Pharmacology, Riphah Institute of Pharmaceutical Sciences, Riphah International University, Islamabad, \\ Pakistan, ${ }^{2}$ Neurobiology Laboratory, Atta-ur-Rahman School of Applied Biosciences, National University of Sciences and \\ Technology, Islamabad, Pakistan
}

OPEN ACCESS

Edited by:

Youssef Sari,

University of Toledo, USA

Reviewed by:

Thomas Heinbockel,

Howard University, USA

Víctor López,

Universidad San Jorge, Spain

*Correspondence:

Arif-ullah Khan

arif.ullah@riphah.edu.pk

Specialty section:

This article was submitted to

Neuropharmacology,

a section of the journal

Frontiers in Pharmacology

Received: 18 September 2016 Accepted: 05 December 2016

Published: 21 December 2016

Citation:

Khan AW, Khan A-U and Ahmed T (2016) Anticonvulsant, Anxiolytic, and Sedative Activities of Verbena officinalis. Front. Pharmacol. 7:499, doi: 10.3389/fphar.2016.00499
We describe different neuropharmacological effects of Verbena officinalis crude extract (Vo.Cr). Pentylenetetrazole (PTZ)-induced seizures, elevated plus maze, light-dark box (LDB), open field and thiopental-induced sleeping test models were employed to evaluate Vo.Cr actions in mice. Vo.Cr dose-dependently $(100-500 \mathrm{mg} / \mathrm{Kg}$ ) delayed onset time of myoclonic jerks and tonic-clonic seizures, while decreased duration of tonic-clonic seizures ( $P<0.05, P<0.001$ vs. saline group). Vo.Cr at 100 and 300$500 \mathrm{mg} / \mathrm{Kg}$ doses reduced animals' mortality in PTZ-induced seizures test to 75 and $0 \%$, respectively. Vo.Cr (50-300 mg/Kg) significantly increased time spent and number of entries into open arms, while decreased time spent and number of entries into closed arms $(P<0.05, P<0.01, P<0.001$ vs. saline group), measured in elevated plus maze. Vo.Cr (50-300 mg/Kg) increased time spent in light compartment, while decreased time spent in dark compartment ( $P<0.01, P<0.001$ vs. saline group) in LDB, like caused by diazepam. In open field test, $\mathrm{Vo}$. $\mathrm{Cr}$ decreased number of ambulations and rearings frequencies, while increased the number of central squares crossings. In thiopentalinduced sleeping test, $\mathrm{Vo} . \mathrm{Cr}(50-300 \mathrm{mg} / \mathrm{Kg})$ decreased onset time of sleep, while increased the duration of sleep $(P<0.05, P<0.01, P<0.001 \mathrm{vs}$. saline group). These results indicate that Verbena officinalis possess anticonvulsant, anxiolytic and sedative activities, which provides scientific background for its medicinal application in various neurological ailments, such as epilepsy, anxiety, and insomnia.

Keywords: Verbena officinalis, anticonvulsant, anxiolytic, sedative, PTZ, EPM

\section{INTRODUCTION}

Verbena officinalis is a perennial herb, belongs to family Verbenaceae, commonly known as "Vervian," "Herb of grace," "Pigeon's grass" and localy "Karenta" or "Pamukh." It mostly grows in Europe and Asia, commonly found in cultivated fields and wastelands near water and cultivated in Northern and Western areas of Pakistan (Jafri et al., 1974; Khan et al., 2015). It grows up to height of about $1 \mathrm{~m}$, having lobed and toothed leaves, while flowers are elegant, silky and pale purple in color (Voogelbreinde, 2009). In traditional system of medicine, Verbena officinalis has been used for treatment of melancholia, hysteria, seizures, jaundice, fever, cholecystaliga, anxiety, depression, insomnia, menstrual disorders (Khare, 2007), abdominal problems, malaria, pharyngitis, edema (Kou et al., 2013), cough, asthma (Vitalini et al., 2009), rheumatic and thyroid problems 
(Guarrera et al., 2005) etc. The constituents isolated from Verbena officinalis include verbenin, verbenalin, hastatoside, alpha-sitosterol, ursolic acid, oleanolic acid (Duke, 1992), kaempferol, luteolin (Chen et al., 2006), verbascoside, aucubin, apigenin, scutellarein (Rehecho et al., 2011) and essential oils like limonene, cineole, spathulenol, ar-curcumeme (Chalchat and Garry, 1995). The plant is reported to possess antitussive (Gui and Tang, 1985), analgesic, anti-inflammatory (Calvo, 2006), neuroprotective (Lai et al., 2006), Antiradical (Speroni et al., 2007), antioxidant, antifungal (López et al., 2008), antitumor (Kou et al., 2013), antibacterial (Mengiste et al., 2015), Antiproliferative (Encalada et al., 2015), and antidepressant (Kamal et al., 2015) activities. In this investigation, we report anticonvulsant, anxiolytic and sedative actions of Verbena officinalis, which explains its ethno-medicinal use in neurological disorders.

\section{MATERIALS AND METHODS}

\section{Plant Material and Extraction}

Verbena officinalis whole plant $(3.2 \mathrm{Kg})$ was collected from National Industrial State, Rawat, Islamabad, Pakistan and was verified by Dr. Mushtaq Ahmad, a Plant Taxonomist, Department of Plant Science, Quaid-e-Azam University, Islamabad, Pakistan. A voucher specimen number 270 was deposited at the same Department for future reference. The plant material was shade dried until water evaporated completely and then grinded. The coarse powder $(2.7 \mathrm{Kg})$ was macerated in $70 \%$ aqueous-methanol under room conditions for 2 -weeks with gentle occasional shaking. The extract was filtered and then concentrated in vacuum under reduced pressure using rotary evaporator to obtain a blackish thick paste of Verbena officinalis crude extract (Vo.Cr), which was completely solublized in normal saline $(0.9 \% \mathrm{w} / \mathrm{v})$. The percentage yield of extract was found to be $18.66 \% \mathrm{w} / \mathrm{w}$.

\section{Animals}

Swiss albino mice (25-35 g) of either sex were used for this study, housed in Animal House of Riphah Institute of Pharmaceutical Sciences in polypropylene $(22 \mathrm{~cm} \times 37 \mathrm{~cm})$ cages under standard laboratory environment; $25 \pm 2{ }^{\circ} \mathrm{C}$, light and darkness duration were for $12 \mathrm{~h}$ each and had free access to standard diet and water ad libitum. Experiments performed complied with rules of Institute of Laboratory Animal Resources, Commission on Life Sciences University, National Research Council (1996), approved by Ethical Committee of Riphah Institute of Pharmaceutical Sciences (Ref. No: REC/RIPS/2015/006).

\section{Drugs and Chemicals}

Diazepam (Valium $10 \mathrm{mg} / 2 \mathrm{~mL}$ injection), pentylenetetrazole (PTZ) and thiopental sodium (Pentothal $500 \mathrm{mg}$ dry powder for injection) were obtained from Roche Pharmaceuticals, Pakistan, Sigma-Aldrich, Co. LLC, USA and Abbot Laboratories, Pakistan, respectively.

\section{EXPERIMENTAL PROTOCOLS}

\section{Anticonvulsant Study \\ PTZ-Induced Seizures}

Mice were divided into five groups (each having four animals) and injected (i.p) with normal saline $(10 \mathrm{~mL} / \mathrm{Kg}), \operatorname{Vo} \mathrm{Cr}(100-$ $500 \mathrm{mg} / \mathrm{Kg}$ ), and diazepam (1 mg/Kg). Thirty min later to saline, Vo.Cr and diazepam treatment, an i.p. dose of PTZ (90 $\mathrm{mg} / \mathrm{Kg}$ ) was given to all animals and each animal was observed for onset time of myoclonic jerks and tonic-clonic seizures, as well as duration of tonic-clonic seizures for $30 \mathrm{~min}$. Drugs that delayed onset of myoclonic jerks, tonic-clonic seizures and/or shortened duration of tonic-clonic seizures are considered to exhibit anticonvulsant effect (Bum et al., 2008; Ya'u et al., 2008). The animals were also observed for mortality (\% mortality $=$ number of mice died after convulsion/total number of mice used $\times 100)$.

\section{Anxiolytic Assays Elevated Plus Maze (EPM)}

Test EPM model consist of a wooden apparatus having four arms (two open arms of $30 \mathrm{~cm} \times 5 \mathrm{~cm}$ and two closed arms of $30 \mathrm{~cm} \times 5 \mathrm{~cm} \times 15 \mathrm{~cm})$ connected via a central opened area $(5 \mathrm{~cm} \times 5 \mathrm{~cm})$, elevated up to $40 \mathrm{~cm}$ from the floor, as previously described (Karim et al., 2012). The edges of open arms are surrounded by $3 \mathrm{~mm}$ high and $1 \mathrm{~mm}$ thick wall. Mice were divided into five groups (each having four animals), received an i.p. dose of normal saline $(10 \mathrm{~mL} / \mathrm{Kg})$ and Vo.Cr $(50-300 \mathrm{mg} / \mathrm{Kg})$ once/day for 7 days, while one group was treated with diazepam $(2 \mathrm{mg} / \mathrm{Kg})$, injected once time $30 \mathrm{~min}$ prior to test. After $30 \mathrm{~min}$ of saline, Vo.Cr and diazepam treatment, a 5 min test was performed by placing each mouse on central area and recorded time spent and number of entries into open and closed arms, via a digital video camera. An entry was considered, when mouse placed all four paws in any arm. The total number of entries into and total time spent in open and closed arms were calculated for determining anxiolytic activity. Following each trial, apparatus was cleaned with $70 \%$ aqueous-ethanol.

\section{Light-Dark Box (LDB) Technique}

Light-dark box (LDB) model contains wooden box of dimensions $44 \mathrm{~cm} \times 21 \mathrm{~cm} \times 21 \mathrm{~cm}$ and divided into a small compartment $(1 / 3 \mathrm{rd})$, painted black inside and covered with a wooden lid and a large compartment (2/3rd) which was painted white, covered by a transparent glass and illuminated by a 60 watt bulb. The two compartments were separated by a wooden blank, having a hole of $7 \mathrm{~cm} \times 7 \mathrm{~cm}$ in center at surface of floor. Mice were divided into five groups (each having four animals), received an i.p. dose of normal saline $(10 \mathrm{~mL} / \mathrm{Kg})$ and Vo.Cr (50-300 mg/Kg) once/day for 7 days, while one group was treated with diazepam $(2 \mathrm{mg} / \mathrm{Kg})$, injected once time $30 \mathrm{~min}$ prior to test. After $30 \mathrm{~min}$ of saline, $\mathrm{Vo}$.Cr and diazepam treatment, a 5 min test was performed by placing each mouse in center of lighted box, keeping face away of opening hole and time spent in each compartment was recorded via a digital video camera (Belzung et al., 1987; Bourin and Hascoet, 2003). 


\section{Open Field Test}

The apparatus is made of a wooden base divided into 12 equal squares with glass walls of dimensions $(50 \mathrm{~cm} \times 25 \mathrm{~cm} \times 50 \mathrm{~cm})$. Mice were divided into five groups (each having four animals), received an i.p. dose of normal saline $(10 \mathrm{~mL} / \mathrm{Kg})$ and $\mathrm{Vo.Cr}$ (50-300 $\mathrm{mg} / \mathrm{Kg}$ ) once/day for 7 days, while one group was treated with diazepam $(2 \mathrm{mg} / \mathrm{Kg})$, injected once time $30 \mathrm{~min}$ prior to test. After $30 \mathrm{~min}$ of saline, $\mathrm{Vo} . \mathrm{Cr}$ and diazepam treatment, a 5 min test was performed by placing each mouse in corner square to explore the arena and recorded numbers of ambulations, rearings, and central squares crossings (Brown et al., 1999; Maurmann et al., 2011), via digital video camera. Ambulations mean number of total squares crossed by mice, rearings are the number of times mice stood on its hind limbs and central squares crossings are the number of times mice entered the central squares with its all four paws. Central squares are those that are not adjacent to arena walls. A square number was counted when mice enter in square with all four paws.

\section{Sedative Activity \\ Thiopental-Induced Sleeping Assay}

Thiopental-induced sleeping test was used for determining sedative activity (Alnamer et al., 2012). Mice were divided into five groups (each having four animals), received an i.p. dose of normal saline $(10 \mathrm{~mL} / \mathrm{Kg})$, Vo.Cr $(50-300 \mathrm{mg} / \mathrm{Kg})$, and diazepam (3 $\mathrm{mg} / \mathrm{Kg}$ ). Thirty min later to saline, Vo.Cr and diazepam treatment, an i.p. dose of thiopental sodium $(50 \mathrm{mg} / \mathrm{Kg})$ was given to all animals for induction of sleep. As thiopental sodium was injected, mice were placed in a test arena for observing the onset and duration of sleep.

\section{Acute Toxicity Test}

Mice in two groups were administered with Vo.Cr high doses of 3 and $5 \mathrm{~g} / \mathrm{Kg}$, i.p, then kept under observation for $24 \mathrm{~h}$ and observed for toxicity symptoms or death.

\section{Statistical Analysis}

Data expressed are mean \pm standard error of mean (SEM, $n=$ number of experiments). The statistical parameter applied is one-way analysis of variance (ANOVA) with Tukey post hoc test. $P<0.05$ was noted as significantly different. The bar-graphs were analyzed using Graph Pad program (GraphPAD, San Diego, CA, USA).

\section{RESULTS}

\section{Effect on PTZ-Induced Seizures}

Vo.Cr dose-dependently (100-500 mg/Kg) delayed onset time of PTZ (90 mg/Kg) mediated both myclonic jerks and tonic-clonic seizures, while decreased duration time of tonic-clonic seizures (Figure 1). In control saline group, onset times of myoclonic jerks, tonic-clonic seizures and duration of tonic-clonic seizures were $35.25 \pm 5.39,42 \pm 5.05$, and $45 \pm 2.74$ s, respectively. In Vo.Cr $(100 \mathrm{mg} / \mathrm{Kg})$ treated group, onset times of myoclonic jerks and tonic-clonic seizures increased to $55.25 \pm 6.09$ and

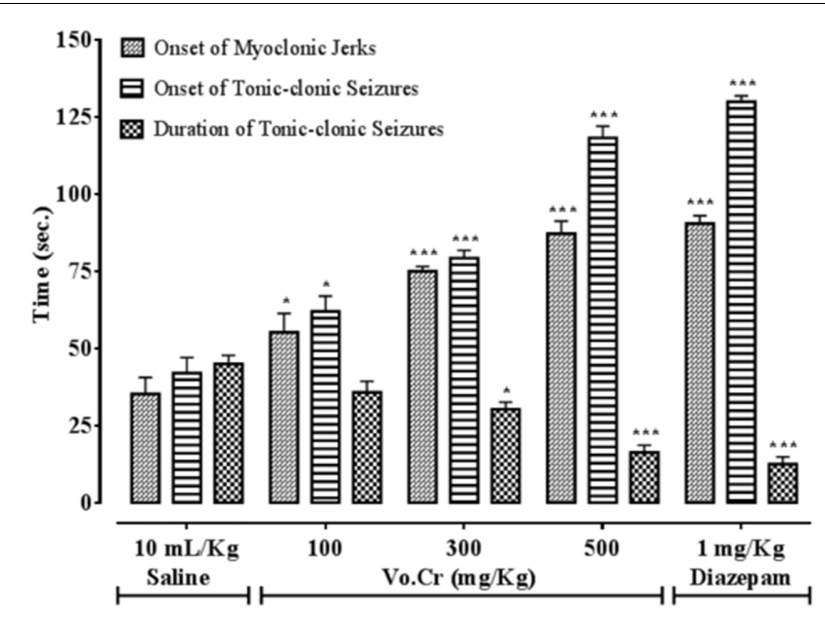

FIGURE 1 | Bar-graph showing effects of Verbena officinalis crude extract (Vo.Cr) and diazepam on onset time of pentylenetetrazole-induced myoclonic jerks, tonic-clonic seizures and duration of tonic-clonic seizures in mice. Data expressed as mean \pm SEM, $n=4 .{ }^{*} P<0.05,{ }^{* * *} P<0.001$ vs. saline group, one-way ANOVA with post hoc Tukey test.

$62 \pm 4.97$ s, respectively ( $P<0.05$ vs. saline group), while duration time of tonic-clonic seizures reduced to $35.75 \pm 3.59 \mathrm{~s}$. In Vo.Cr $(300 \mathrm{mg} / \mathrm{Kg})$ treated group, onset times of myoclonic jerks and tonic-clonic seizures increased to $75 \pm 1.58$ and $79.25 \pm 2.56 \mathrm{~s}$, respectively ( $P<0.001$ vs. saline group), while duration time of tonic-clonic seizures reduced to $30.25 \pm 2.32 \mathrm{~s}$ ( $P<0.05$ vs. saline group). In Vo.Cr $(500 \mathrm{mg} / \mathrm{Kg})$ treated group, onset times of myoclonic jerks and tonic-clonic seizures increased to $87.25 \pm 4.03$ and $118.25 \pm 3.79 \mathrm{~s}$, respectively, while duration time of tonic-clonic seizures reduced to $16.25 \pm 2.39 \mathrm{~s}(P<0.001$ vs. saline group). In diazepam $(1 \mathrm{mg} / \mathrm{Kg})$ treated group, onset times of myoclonic jerks and tonic-clonic seizures increased to $90.5 \pm 2.53$ and $130 \pm 1.87 \mathrm{~s}$, respectively, while duration time of tonic-clonic seizures reduced to $12.5 \pm 2.33 \mathrm{~s}(P<0.001$ vs. saline group). The saline treated group animals showed $100 \%$ mortality and immediately died. Vo.Cr at $100 \mathrm{mg} / \mathrm{Kg}$ and $300-500 \mathrm{mg} / \mathrm{Kg}$ doses reduced PTZ-induced seizures mortality rate to 75 and $0 \%(P<0.05, P<0.001$ vs. saline group) respectively, while diazepam at test dose of $1 \mathrm{mg} / \mathrm{Kg}$, reduced mortality to $0 \%(P<0.001$ vs. saline group) as shown in Table 1.

\section{Effect on Time Spent in Open and Closed Arms}

Vo.Cr at 50-300 mg/Kg increased time spent by animals in open arms, while decreased time spent in closed arms (Figure 2). In control saline group, time spent in open and closed arms were $23 \pm 3.11$ and $221 \pm 9.57$ s, respectively. In Vo.Cr $(50 \mathrm{mg} / \mathrm{Kg})$ treated group, time spent in open arms increased to $51.75 \pm 4.72 \mathrm{~s}$ while time spent in closed arms reduced to $176 \pm 7.52 \mathrm{~s}(P<0.01$ vs. saline group $)$. In Vo.Cr $(100 \mathrm{mg} / \mathrm{Kg})$ treated group, time spent in open arms increased to $113 \pm 5.31 \mathrm{~s}$ while time spent in closed arms reduced to $129.75 \pm 5.59 \mathrm{~s}$ 
TABLE 1 | Effect of Verbena officinalis crude extract (Vo.Cr) and diazepam on pentylenetetrazole (PTZ)-induced seizures mortality in mice.

\begin{tabular}{ll}
\hline Groups & $\%$ Mortality \\
\hline Saline $(10 \mathrm{~mL} / \mathrm{Kg})+$ PTZ $(90 \mathrm{mg} / \mathrm{Kg})$ & 100.00 \\
$\operatorname{Vo} . \mathrm{Cr}(100 \mathrm{mg} / \mathrm{Kg})+$ PTZ $(90 \mathrm{mg} / \mathrm{Kg})$ & $75.00^{*}$ \\
$\operatorname{Vo} . \mathrm{Cr}(300 \mathrm{mg} / \mathrm{Kg})+$ PTZ $(90 \mathrm{mg} / \mathrm{Kg})$ & $0.00^{* * *}$ \\
$\operatorname{Vo} . \operatorname{Cr}(500 \mathrm{mg} / \mathrm{Kg})+$ PTZ $(90 \mathrm{mg} / \mathrm{Kg})$ & $0.00^{* * *}$ \\
Diazepam $(1 \mathrm{mg} / \mathrm{Kg})+$ PTZ $(90 \mathrm{mg} / \mathrm{Kg})$ & $0.00^{* * *}$ \\
\hline
\end{tabular}

Mortality = number of mice died after convulsion/total number of mice used where $\%$ mortality $=$ (number of mice died after convulsion/total number of mice used) $\times 100$. Data expressed as mean \pm SEM, $n=4 .{ }^{*} P<0.05,{ }^{* * *} P<0.001 \mathrm{vs}$. saline group, one-way ANOVA with post-hoc Tukey test.

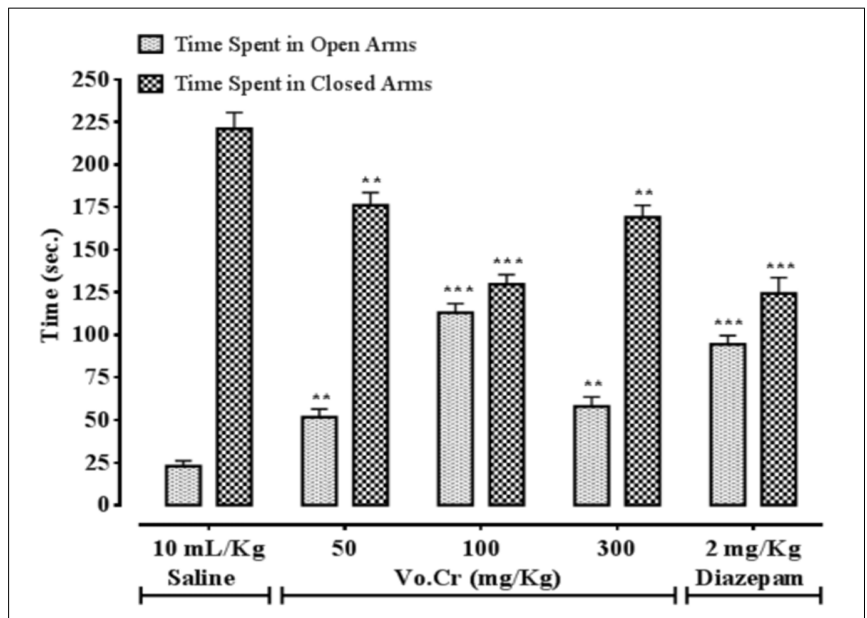

FIGURE 2 | Bar-graph showing effects of Verbena officinalis crude extract (Vo.Cr) and diazepam on time spent by mice in open and closed arms in elevated plus maze model. Data expressed as mean \pm SEM, $n=4 .{ }^{* *} P<0.01,{ }^{* * *} P<0.001$ vs. saline group, one-way ANOVA with post hoc Tukey test.

$(P<0.001$ vs. saline group). In $\operatorname{Vo.Cr}(300 \mathrm{mg} / \mathrm{Kg})$ treated group, time spent in open arms was $58 \pm 5.58 \mathrm{~s}$ while time spent in closed arms was $169 \pm 7.04 \mathrm{~s}(P<0.01$ vs. saline group). In diazepam $(2 \mathrm{mg} / \mathrm{Kg})$ treated group, time spent in open arms was increased to $94.5 \pm 5.06 \mathrm{~s}$ while time spent in closed arms reduced to $124.25 \pm 9.41 \mathrm{~s}(P<0.001$ vs. saline group).

\section{Effect on Number of Entries in Open and Closed Arms}

Vo.Cr at 50-300 mg/Kg increased number of animals' entries into open arms, while decreased number of entries into closed arms (Figure 3). In control saline group, numbers of entries into open and closed arms were $5.75 \pm 1.32$ and $17.25 \pm 1.75$, respectively. In Vo.Cr $(50 \mathrm{mg} / \mathrm{Kg})$ treated group, number of entries into open arms increased to $12.5 \pm 1.32$, while number of entries in closed arms reduced to $10.75 \pm 0.63(P<0.05$ vs. saline group). In Vo.Cr (100 mg/Kg) treated group, number of entries into open arms increased to $13.75 \pm 1.11$, while number of entries in closed arms reduced to $8.0 \pm 1.29(P<0.01$ vs. saline group). In Vo.Cr $(300 \mathrm{mg} / \mathrm{Kg})$ treated group, number

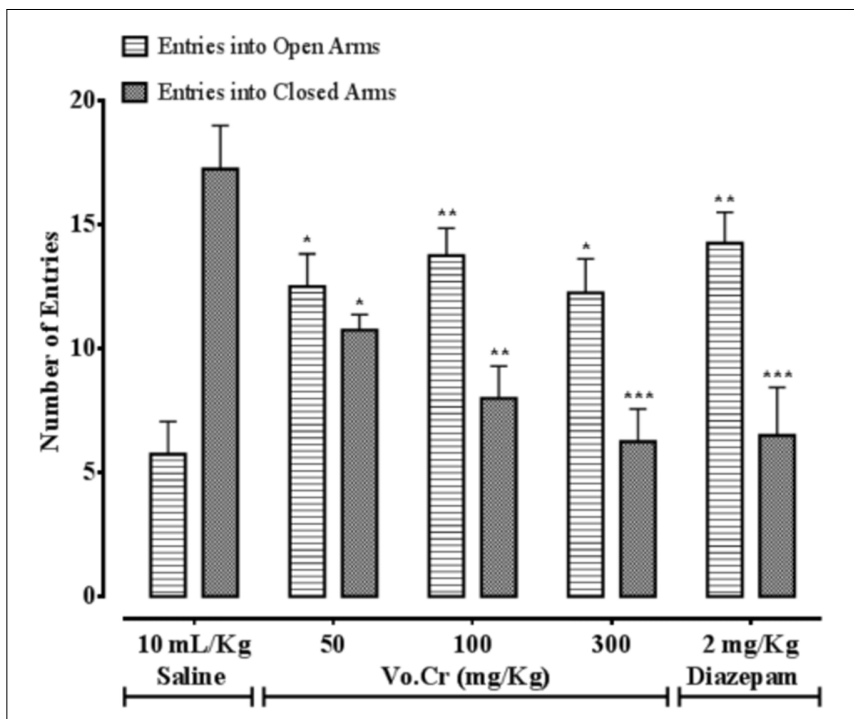

FIGURE 3 | Bar-graph showing effects of Verbena officinalis crude extract (Vo.Cr) and diazepam on numbers of mice entries in open and closed arms in elevated plus maze model. Data expressed as mean \pm SEM, $n=4 .{ }^{*} P<0.05,{ }^{* *} P<0.01,{ }^{* * *} P<0.001$ vs. saline group, one-way ANOVA with post hoc Tukey test.

of entries into open arms were $12.25 \pm 1.38(P<0.05$ vs. saline group), while number of entries in closed arms reduced to $6.25 \pm 1.32(P<0.001$ vs. saline group). In diazepam $(2 \mathrm{mg} / \mathrm{Kg})$ treated group, number of entries into open arms increased to $14.25 \pm 1.25(P<0.01$ vs. saline group), while number of entries in closed arms reduced to $6.5 \pm 1.94(P<0.001$ vs. saline group).

\section{Effect on Time Spent in Light and Dark Compartments}

Vo.Cr at 50-300 mg/Kg increased time spent by animals in light compartment, while decreased time spent in dark compartment (Figure 4). In control saline group, times spent in light and dark compartments were $88.5 \pm 5.25$ and $194.75 \pm 7.25 \mathrm{~s}$, respectively. In $\operatorname{Vo} . \mathrm{Cr}(50 \mathrm{mg} / \mathrm{Kg})$ treated group, time spent in light compartment increased to $138.75 \pm 12.13 \mathrm{~s}$, while time spent in dark compartment reduced to $145 \pm 9.25 \mathrm{~s}(P<0.01$ vs. saline group). In Vo.Cr $(100 \mathrm{mg} / \mathrm{Kg})$ treated group, time spent in light compartment increased to $158 \pm 9.46 \mathrm{~s}$, while time spent in dark compartment reduced to $134 \pm 8.27 \mathrm{~s}(P<0.001$ vs. saline group). In Vo.Cr $(300 \mathrm{mg} / \mathrm{Kg})$ treated group, time spent in light compartment was $142 \pm 7.22 \mathrm{~s}$, while time spent in dark compartment was $151 \pm 4.53 \mathrm{~s}(P<0.01$ vs. saline group). In diazepam $(2 \mathrm{mg} / \mathrm{Kg})$ treated group, time spent in light compartment was $140.5 \pm 4.74 \mathrm{~s}$, while time spent in dark compartment was $144.5 \pm 5.12 \mathrm{~s}(P<0.01$ vs. saline group $)$.

\section{Effect on Numbers of Ambulations, Rearings, and Central Squares Crossings}

Vo.Cr at highest tested dose of $300 \mathrm{mg} / \mathrm{Kg}$, significantly decreased numbers of animals' ambulations and rearings frequencies, 


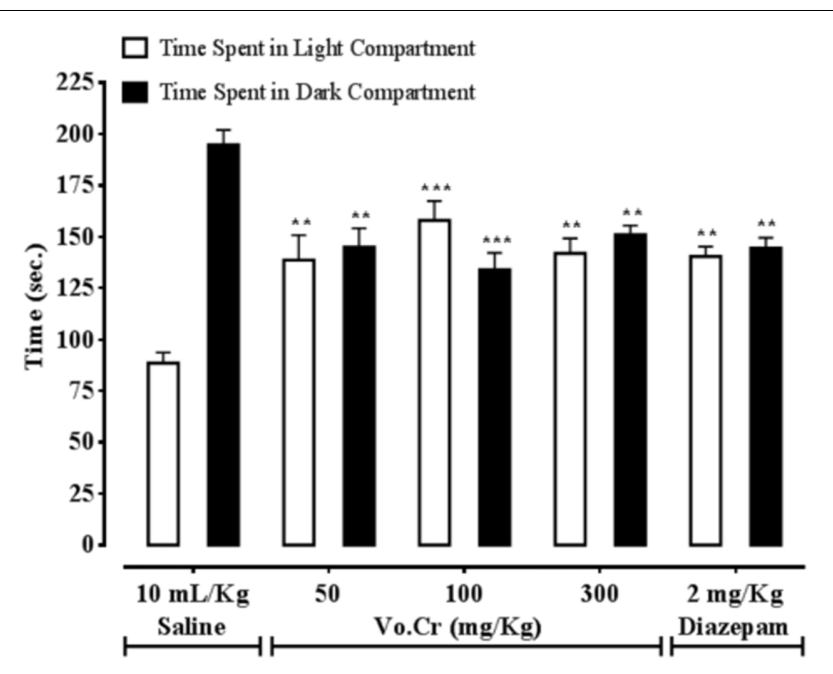

FIGURE 4 | Bar-graph showing effects of Verbena officinalis crude extract (Vo.Cr) and diazepam on time spent by mice in light and dark compartments in light-dark box model. Data expressed as mean $\pm S E M$, $n=4$. ${ }^{* *} P<0.01,{ }^{* * *} P<0.001$ vs. saline group, one-way ANOVA with post hoc Tukey test.

while increased the number of central squares crossings at all tested doses (50-300 $\mathrm{mg} / \mathrm{Kg}$ ) compared to control saline group, as presented in Figure 5. In saline group, numbers of ambulations, rearings, and central squares crossings were $121.75 \pm 9.71,52.25 \pm 4.52$, and $6.25 \pm 0.85$, respectively. In $\operatorname{Vo.Cr}(50 \mathrm{mg} / \mathrm{Kg})$ treated group, numbers of ambulations and rearings were $109.5 \pm 8.06$ and $42.5 \pm 2.22(P>0.05$ vs. saline group) respectively, while number of central squares crossings increased to $11.25 \pm 0.85$ ( $P<0.01$ vs. saline group) In Vo.Cr $(100 \mathrm{mg} / \mathrm{Kg})$ treated group, numbers of ambulations and rearings were $106.5 \pm 4.03$ and $39.5 \pm 2.9(P>0.05$ vs. saline group) respectively, while number of central squares crossings increased to $15 \pm 0.41$ ( $P<0.001$ vs. saline group). In Vo.Cr $(300 \mathrm{mg} / \mathrm{Kg})$ treated group, numbers of ambulations and rearings reduced to $74.25 \pm 3.30$ and $24.25 \pm 1.97$ respectively ( $P<0.001$ vs. saline group), while number of central squares crossings were $10.75 \pm 0.85(P<0.01$ vs. saline group). In diazepam $(2 \mathrm{mg} / \mathrm{Kg})$ treated group, numbers of ambulations and rearings decreased to $70 \pm 4.66$ and $15.25 \pm 2.96$ respectively ( $P<0.001$ vs. saline group), while number of central squares crossings increased to $11 \pm 0.91(P<0.01$ vs. saline group).

\section{Effect on Thiopental-Induced Sleeping Time}

Vo.Cr dose-dependently (50-300 mg/Kg) decreased animals' onset time of sleep, while increased sleep duration (Figures 6A,B). In control saline group, onset and duration of sleep times were $3.53 \pm 0.27$ and $8.25 \pm 1.16 \mathrm{~min}$, respectively. In $\operatorname{Vo.Cr}(50 \mathrm{mg} / \mathrm{Kg})$ treated group, onset time of sleep decreased to $2.61 \pm 0.21 \mathrm{~min}(P<0.05$ vs. saline group), while duration of sleep time was increased to $14.50 \pm 1.57 \mathrm{~min}$. In

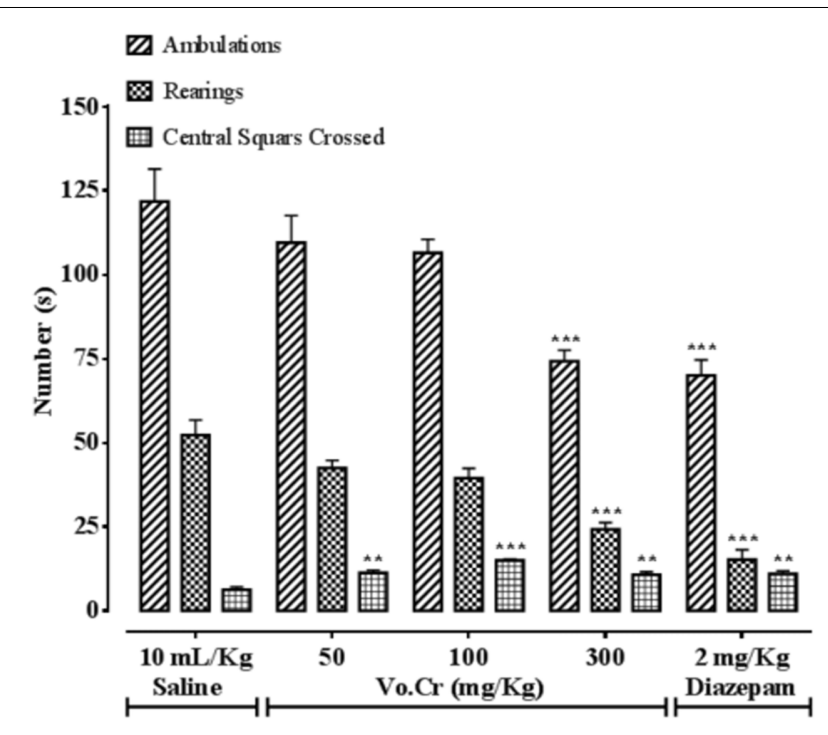

FIGURE 5 | Bar-graph showing effects of Verbena officinalis crude extract (Vo.Cr) and diazepam on numbers of mice ambulations, rearings, and central squares crossings in open field model. Data expressed as mean \pm SEM, $n=4{ }^{* *} P<0.01,{ }^{* * *} P<0.001$ vs. saline group, one-way ANOVA with post hoc Tukey test.

Vo.Cr $(100 \mathrm{mg} / \mathrm{Kg})$ treated group, onset time of sleep was decreased to $2.39 \pm 0.04 \mathrm{~min}$, while duration of sleep time was increased to $66.45 \pm 6.13 \mathrm{~min}$ ( $P<0.01$ vs. saline group). In Vo.Cr $(300 \mathrm{mg} / \mathrm{Kg})$ treated group, onset time of sleep was further decreased to $1.6 \pm 0.14 \mathrm{~min}$, while duration of sleep time was increased to $523.65 \pm 13.03 \mathrm{~min}(P<0.001$ vs. saline group). In diazepam $(3 \mathrm{mg} / \mathrm{Kg})$ treated group, onset time of sleep was $1.32 \pm 0.05 \mathrm{~min}$, while duration of sleep time was $571.8 \pm 12.17 \min (P<0.001$ vs. saline group).

\section{Acute Toxicity}

Vo.Cr at higher doses of 3 and $5 \mathrm{~g} / \mathrm{Kg}$, i.p. did not caused any mortality, but only decreased locomotor activity of mice showing sedative effect.

\section{DISCUSSION}

We employed different pharmacological techniques, to investigate anticonvulsant, anxiolytic and sedative effects of Verbena officinalis. PTZ-induced seizure is commonly used animal model for screening of anti-seizure drugs (Loscher and Schmidt, 1988; Okoye et al., 2013). Vo.Cr caused marked delay in onset time of both myoclonic jerks and tonic-clonic seizures, as well as decreased duration of tonic-clonic seizures and animals' mortality, demonstrating its anti-epileptic effect. PTZ evokes convulsions via inhibition of GABAergeic neurotransmissions by interfering with $\mathrm{GABA}_{\mathrm{A}}$ receptors (Ramanjaneyulu and Ticku, 1984). Dr. Thomas B. Turnbaugh in his professional experience observed verbenin, an iridoid glycoside, obtained from Verbena hastate more beneficial than bromide for epilepsy treatment. He 


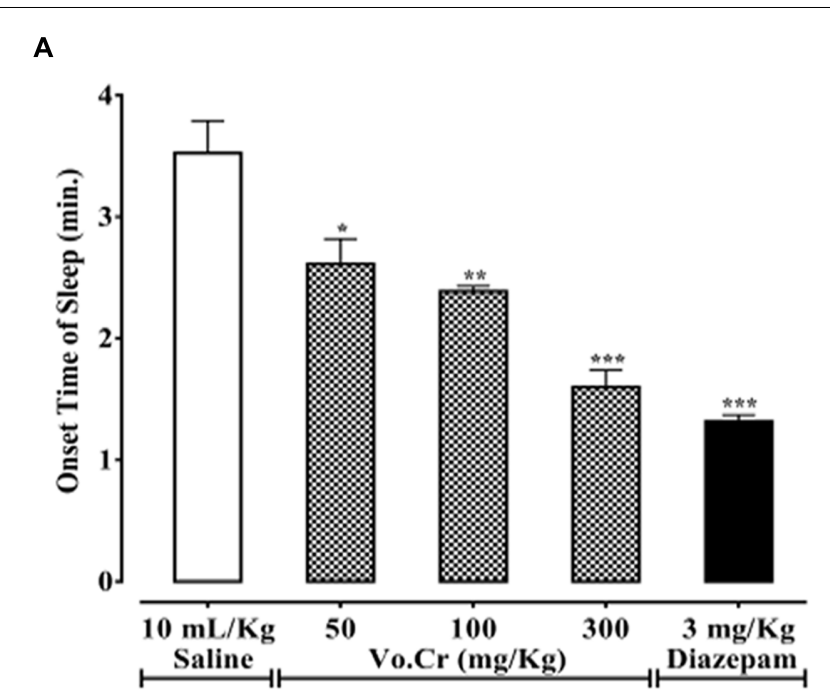

B

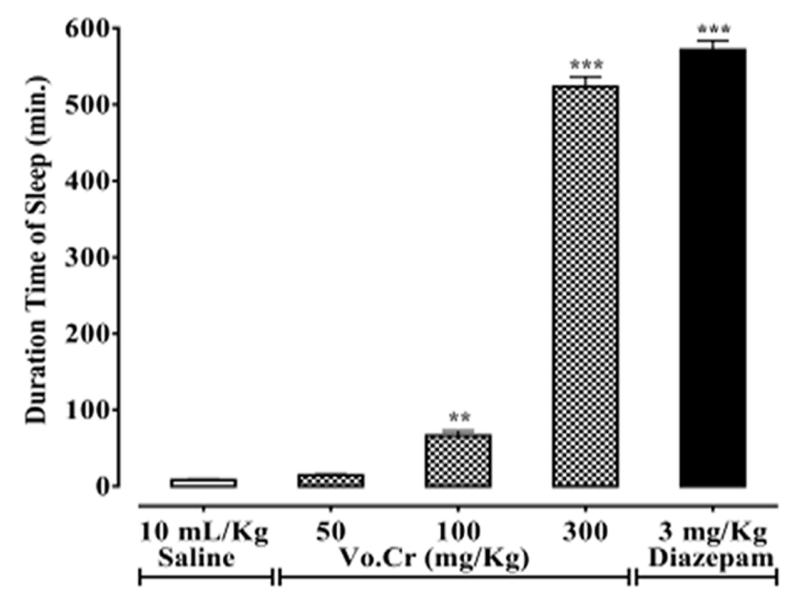

FIGURE 6 | Bar-graph showing effects of Verbena officinalis crude extract (Vo.Cr) and diazepam on (A) onset time of sleep and (B) duration of sleep in thiopental-induced sleeping test in mice. Data expressed as mean \pm SEM, $n=4$. ${ }^{*} P<0.05,{ }^{* *} P<0.01,{ }^{* * *} P<0.001$ vs. saline group, one-way ANOVA with post hoc Tukey test.

favored verbenin that it has no injurious effects and its use makes the patient more cheerful and alert instead of bromide which makes the patient stupid and dull (French, 1908). Verbenin is also the main constituent of Verbena officinalis (Duke, 1992) which might be responsible for its anticonvulsant activity. Verbena officinalis is known to contain a constituent, 4-(1-methylethyl)benzylic alcohol safranal (Gharachorloo and Amouheidari, 2016) and safranal from Crocus sativus plant has been reported for its anti-seizure action by virtue of $\mathrm{GABA}_{\mathrm{A}}$ receptors stimulation (Hosseinzadeh and Talebzadeh, 2005; Hosseinzadeh and Sadeghnia, 2007), suggesting that anticonvulsant effect of Verbena officinalis might possibly occurred through activation of $\mathrm{GABA}_{\mathrm{A}}$ receptors by safranal. EPM and LDB models are favorable for testing of $\mathrm{GABA}_{\mathrm{A}}$-receptors linked anxiolytic drugs
(Emamghoreishi et al., 2005; Mesfin et al., 2014). Agents, which increase animals time spent and number of entries into open arms and/or reducing these phenomenon in closed arms in EPM, also increase animals' time spent in light compartment and/or reducing these phenomenon in dark compartment in LDB, are considered to possess anxiolytic effects (Hellion-Ibarrola et al., 2006). Vo.Cr significantly increased time spent and number of entries into open arms, while deceased time spent and number of entries into closed arms, as well as increased time spent in light compartment, while deceased time spent in dark compartment, like that caused by diazepam, a standard benzodiazepine anxiolytic medicine (Griebel et al., 1998). At the $100 \mathrm{mg} / \mathrm{Kg}$ dose, Vo.Cr showed maximum anxiolytic effect, but at next highest tested dose $(300 \mathrm{mg} / \mathrm{Kg})$, its effect was reduced, because of decreased exploratory activities, possibly be due to co-existent sedative component of the plant. Verbena officinalis has been reported for presence of flavonoids (apigenin, luteolin, quercetion, kaempferol) and tannins (Mengiste et al., 2014; Edwards et al., 2015), which are well-known for their anxiolytic and central nervous system depressant (sedative) activities (Adeyemi et al., 2006; Coleta et al., 2008; Aguirre-Hernandez et al., 2010). Several flavonoids bind to the benzodiazepine site on $\mathrm{GABA}_{\mathrm{A}}$-receptors to provoke anti-seizure, anti-anxiety and sedative effects (Jager and Saaby, 2011), evidencing that observed actions of Verbena officinalis mediated possibly through activation of $\mathrm{GABA}_{\mathrm{A}}$-receptors pathway. However, involvement of other contributing mechanism(s) cannot be ignored. In open field test principle, increased number of ambulations, rearings and central squares crossings reveal anxiolytic activity, while reduction in locomotion showed sedative effect. Vo.Cr at lower doses of $50-100 \mathrm{mg} / \mathrm{Kg}$ did not produced statistically any prominent difference in ambulation and rearing frequencies, compared to saline group $(P>0.05)$, but both ambulation and rearing frequencies were significantly reduced at highest dose of $300 \mathrm{mg} / \mathrm{Kg}(P<0.001$ vs. saline group). The decreased locomotor activity at higher dose of $\mathrm{Vo} . \mathrm{Cr}$ might be due to sedative effect of the plant. Vo.Cr, at all tested doses $(50-300 \mathrm{mg} / \mathrm{Kg}$ ) significantly increased numbers of central squares crossings, showing its anxiolytic activity. Diazepam, a reference drug also reduced both ambulation and rearing frequencies, because of its sedative property, while increased the number of central squares crossings, due to owning anxiolytic profile (Ramos, 2008). Benzodiazepines are well-established for anxiolytic effect at lower doses and sedative, muscle relaxant and anti seizure effects at higher doses (Melo et al., 2006). Substances that have sedative effect either decrease onset time of sleep and/or prolong duration of sleep (Raquibul-Hasan et al., 2009). In thiopental-induced sleeping assay, Vo.Cr in dose-dependent manner decreased onset time of sleep, while increased duration of sleep, indicating its sedative activity, further confirming that the decreased locomotor activity of mice in EPM, light-dark and open field tests was due to sedative effect of the plant test extract. Flavonoids like scutellarein and phenolic acid derivatives like verbascoside have been reported for their sedative effects but they have low affinity for benzodiazepine site on $\mathrm{GABA}_{\mathrm{A}}$ receptor. The authors suggest that they could induce CNS activities through different mechanism like 
inhibition of the $N$-methyl-D-aspartate or serotonin receptors and the type of sugar linkage with the aglycone should be an important factor for their sedative activities (De Santana Julião et al., 2010). Scutellarein and verbascoside are the main constituents of Verbena officinalis (Rehecho et al., 2011), so sedative effect of Verbena officinalis may be due to these constituents possibly through GABA pathways by acting on sites other than benzodiazepine ones or through pathways other than GABAergic system.

\section{CONCLUSION}

The present study reveals that Verbena officinalis exhibits anticonvulsant, anxiolytic and sedative effects, which validates its folk use in neurological disorders and a step forward toward

\section{REFERENCES}

Adeyemi, O. O., Yemitan, O. K., and Taiwo, A. E. (2006). Neurosedative and muscle - relaxant activities of ethyl acetate extract of Baphia nitida AFZEL. J. Ethnopharmacol. 106, 312-316. doi: 10.1016/j.jep.2005.11.035

Aguirre-Hernandez, E., Gonzalez-Trujano, M. E., Martínez, A. L., Moreno, J., Kite, G., Terrazas, T., et al. (2010). HPLC/MS analysis and anxiolytic-like effect of quercetin and kaempferol flavonoids from Tilia americana var. Mexicana. J. Ethnopharmacol. 127, 91-97. doi: 10.1016/j.jep.2009.09.044

Alnamer, R., Alaoui, K., Bouidida, E. H., Benjouad, A., and Cherrah, Y. (2012). Sedative and hypnotic activities of the methanolic and aqueous extracts of lavandula officinalis from Morocco. Adv. Pharmacol. Sci. 2012:270824. doi: $10.1155 / 2012 / 270824$

Belzung, C., Misslin, R., Vogel, E., Dodd, R. H., and Chapouthier, G. (1987). Anxiogenic effects of methyl-beta-carboline-3-carboxylate in light/dark choice situation. Pharmacol. Biochem. Behav. 28, 29-33. doi: 10.1016/0091-3057(87) 90006-2

Bourin, M., and Hascoet, M. (2003). The mouse light/dark box test. Eur. J. Pharmacol. 463, 55-65. doi: 10.1016/S0014-2999(03)01274-3

Brown, R. E., Corey, S. C., and Moore, A. K. (1999). Differences in measures of exploration and fear in MHC-congenic C57BL/6J and B6-H-2K mice. Behav. Genet. 26, 263-271. doi: 10.1023/A:1021694307672

Bum, E. N., Ngoupaye, G. T., Talla, E., Dimo, T., Kantchoua, G. C. N., Pelanken, M. M., et al. (2008). The anticonvulsant and sedative properties of stems of Cissus quadrangularis in mice. Afr. J. Pharm. Pharacol. 2, 42-47.

Calvo, M. I. (2006). Anti-inflammatory and analgesic activity of the topical preparation of Verbena officinalis L. J. Ethnopharmacol. 107, 380-382. doi: 10.1016/j.jep.2006.03.037

Chalchat, J. C., and Garry, R. P. (1995). Chemical composition of the leaf oil of Verbena officinalis L. J. Essent. Oil Res. 8, 419-420. doi: 10.1080/10412905.1996. 9700653

Chen, G. M., Zhang, J. Y., Zhang, X. P., and Liu, H. M. (2006). Study on chemical composition of flavonoids in Verbena officinalis. J. Chin. Med. Mater. 29, 677-679.

Coleta, M., Campos, M. G., Cotrim, M. D., Lima, T. C., and Cunha, A. P. (2008). Assessment of luteolin $\left(3^{\prime}, 4^{\prime}, 5,7\right.$-tetrahydroxyflavone) neuropharmacological activity. Behav. Brain Res. 189, 75-82. doi: 10.1016/j.bbr.2007. 12.010

De Santana Julião, L., Leitão, S. G., Lotti, C., Picinelli, A. L., Rastrelli, L., Fernandes, P. D., et al. (2010). Flavones and phenylpropanoids from a sedative extract of Lantana trifolia L. Phytochemistry 71, 294-300. doi: 10.1016/j.phytochem.2009. 10.007

Duke, J. A. (1992). Handbook of Phytochemical Constituent Grass, Herbs and other Economic Plants. Boca Raton, FL: CRC Press, 624.

Edwards, S. E., Rocha, I. C., Williamson, E. M., and Heinrich, M. (2015). Phytopharmacy: An Evidence-Based Guide to Herbal Medicinal Products. West Sussex: Wiley-Blackwell, 386. exploration of evidence-based alternative medicines. Further indepth advance molecular studies are warranted to elucidate pharmacodynamics basis of the pharmacological actions.

\section{AUTHOR CONTRIBUTIONS}

AK performed this research work under the supervision of A-uK and co-supervision TA.

\section{ACKNOWLEDGMENT}

The authors are thankful to Riphah Academy of Research and Education, Islamic International Medical College Trust, Riphah International University for partial financial support of the study.

Emamghoreishi, M., Khasaki, M., and Aazam, M. F. (2005). Coriandrum sativum: evaluation of its anxiolytic effect in the elevated plus-maze. J. Ethnopharmacol. 96, 365-370. doi: 10.1016/j.jep.2004.06.022

Encalada, M. A., Rehecho, S., Ansorena, D., Astiasarán, I., Cavero, R. Y., and Calvo, M. I. (2015). Antiproliferative effect of phenylethanoid glycosides from Verbena officinalis L. on colon cancer cell lines. LWT Food Sci. Technol. 63, 1016-1022. doi: 10.1016/j.lwt.2015.03.065

French, J. M. (1908). Is verbenin a cure for epilepsy? Ellingwoods Ther. 2:15.

Gharachorloo, M., and Amouheidari, M. (2016). Chemical composition, antibacterial and antioxidant activities of the essential oil isolated from Verbena officinalis. J. Food Biosci. Technol. 6, 33-40.

Griebel, G., Perrault, G., and Sanger, D. J. (1998). Characterization of the behavioral profile of the non-peptide CRF receptor antagonist CP-154, 526 in anxiety model in rodents comparison with diazepam and buspirone. Psychopharmacology 138, 55-66. doi: 10.1007/s002130050645

Guarrera, P. M., Forti, G., and Marignoli, S. (2005). Ethnobotanical and ethnomedicinal uses of plants in the district of Acquapendente (Latium, Central Italy). J. Ethnopharmacol. 96, 429-444. doi: 10.1016/j.jep.2004.09.014

Gui, C. H., and Tang, R. J. (1985). Study on antitussive active ingredients of Verbena officinalis. Bull. Chin. Mater. Med. 10:35.

Hellion-Ibarrola, M. C., Ibarrola, D. A., Montalbetti, Y., Kennedy, M. L., Heinichen, O., Campuzanoa, M., et al. (2006). The anxiolytic-like effects of Aloysia polystachya (Griseb.) Moldenke (Verbenaceae) in mice. J. Ethnopharmacol. 105, 400-408. doi: 10.1016/j.jep.2005.11.013

Hosseinzadeh, H., and Sadeghnia, H. R. (2007). Protective effect of safranal on pentylenetetrazol-induced seizures in the rat: involvement of GABAergic and opioids systems. Phytomedicine 14, 256-262. doi: 10.1016/j.phymed.2006. 03.007

Hosseinzadeh, H., and Talebzadeh, F. (2005). Anticonvulsant evaluation of safranal and crocin from Crocus sativus in mice. Fitoterapia 76, 722-724. doi: 10.1016/j. fitote.2005.07.008

Jafri, S. M. H., Nasir, S. G., and Ali, S. I. (1974). Flora of Pakistan. Karachi: Karachi University Press.

Jager, A. K., and Saaby, L. (2011). Flavonoids and the CNS. Molecules 16, 1471-1485. doi: 10.3390/molecules 16021471

Kamal, M., Jawaid, T., and Imam, S. A. (2015). Antidepressant activity of methanolic extract of Verbena officinalis Linn plant in mice. Asian J. Pharm. Clin. Res. 8, 308-310.

Karim, N., Curmi, J., Gavande, N., Johnston, G. A., Hanrahan, J. R., Tierney, M. L., et al. (2012). 2'-Methoxy-6-methylflavone: a novel anxiolytic and sedative with subtype selective activating and modulating actions at GABAA receptors. $\mathrm{Br}$. J. Pharmacol. 165, 880-896. doi: 10.1111/j.1476-5381.2011.01604.x

Khan, A. M., Qureshi, R., Qaseem, M. F., Munir, M., Ilyas, M., and Saqib, Z. (2015). Floristic checklist of district kotli, azad jammu \& kashmir. Pak. J. Bot. 47, 1957-1968.

Khare, C. P. (2007). Indian Medicinal Plants. An Illustrated Dictionary. Heidelberg: Springer, 698. 
Kou, W. Z., Yang, J., Yang, Q. H., Wang, Y., Wang, Z. F., Xu, S. L., et al. (2013). Study on in-vivo anti-tumor activity of Verbena officinalis extract. Afr. J. Tradit. Complement. Altern. Med. 10, 512-517. doi: 10.4314/ajtcam.v10i3.19

Lai, S. W., Yu, M. S., Yuen, W. H., and Chang, R. C. (2006). Novel neuroprotective effects of the aqueous extracts from Verbena officinalis Linn. Neuropharmacology 50, 641-650. doi: 10.1016/j.neuropharm.2005.11.009

López, V., Akerreta, S., Casanova, E., García-Mina, J., Cavero, R., and Calvo, M. (2008). Screening of Spanish medicinal plants for antioxidant and antifungal activities. Pharm. Biol. 46, 602-609. doi: 10.1080/13880200802179634

Loscher, W., and Schmidt, D. (1988). Which animal models should be used in the search for new antiepileptic drugs? A proposal based on experimental and clinical considerations. Epilepsy Res. 2, 145-181. doi: 10.1016/0920-1211(88) 90054-X

Maurmann, N., Reolon, G. K., Rech, S. B., Fett-Neto, A. G., and Roesler, R. (2011). A valepotriate fraction of Valeriana glechomifolia shows sedative and anxiolytic properties and impairs recognition but not aversive memory in mice. Evid. Based Complement. Alternat. Med 2011:720853. doi: 10.1093/ecam/ nep 232

Melo, C. T. V., Monteiro, A. P., Leite, C. P., Araújo, F. L., Lima, V. T., Barbosa-Filho, J. M., et al. (2006). Anxiolytic-like effects of (O-methyl)N-2,6-dihydroxybenzoyl-tyramine (Riparin III) from Aniba riparia (NeeS) Mez (Lauraceae) in mice. Biol. Pharm. Bull. 29, 451-454. doi: 10.1248/bpb. 29.451

Mengiste, B., Lulie, S., Getachew, B., Gebrelibanos, M., Mekuria, A., and Masresha, B. (2015). In vitro antibacterial activity of extracts from aerial parts of Verbena officinalis. Adv. Biol. Res. 9, 53-57. doi: 10.5829/idosi.abr.2015.9.1.1114

Mengiste, B., Yesufn, J. M., and Getachew, B. (2014). In-vitro antibactserial activity and phytochemical analysis of leaf extract of Verbena officinalis. Int. J. Pharmacogn. 1, 744-779.

Mesfin, M., Asres, K., and Shibeshi, W. (2014). Evaluation of anxiolytic activity of the essential oil of the aerial part of Foeniculum vulgare miller in mice. BMC Complement. Altern. Med. 14:310. doi: 10.1186/1472-6882-14-310

Okoye, T. C., Akah, P. A., Omeje, E. O., Okoye, F. B. C., and Nworu, C. S. (2013). Anticonvulsant effect of kaurenoic acid isolated from the root bark of Annona senegalensis. Pharmacol. Biochem. Behav. 109, 38-43. doi: 10.1016/j.pbb.2013. 05.001
Ramanjaneyulu, R., and Ticku, M. K. (1984). Interactions of pentamethylenetetrazole and tetrazole analogues with the picrotoxinin site of the benzodiazepine-GABA receptor-ionophore complex. Eur. J. Pharmacol. 98, 337-345. doi: 10.1016/0014-2999(84)90282-6

Ramos, A. (2008). Animal models of anxiety: do I need multiple tests? Trends Pharmacol. Sci. 10, 493-498. doi: 10.1016/j.tips.2008.07.005

Raquibul-Hasan, S. M., Hossain, M. M., Akter, R., Jamila, M., Mazumder, E. H., and Rahman, S. (2009). Sedative and anxiolytic effects of different fractions of the Commelina benghalensis Linn. Drug Discov. Ther. 3, 221-227.

Rehecho, S., Hidalgo, O., de Cirano, M. G. I., Navarro, I., Astiasarán, I., Ansorena, D., et al. (2011). Chemical composition, mineral content and antioxidant activity of Verbena officinalis L. LWT Food Sci. Technol. 44, 875-882. doi: 10.1016/j.lwt.2010.11.035

Speroni, E., Cervellati, R., Costa, S., Guerra, M. C., Utan, A., Govoni, P., et al. (2007). Effects of differential extraction of Verbena officinalis on rat models of inflammation, cicatrization and gastric damage. Planta Med. 73, 227-235. doi: 10.1055/s-2007-967116

Vitalini, S., Tome, F., and Fico, G. (2009). Traditional uses of medicinal plants in Valvestino (Italy). J. Ethnopharmacol. 12, 106-116. doi: 10.1016/j.jep.2008. 10.005

Voogelbreinde, S. (2009). Garden of Eden: The Shamanic Use of Psychoactive Flora and Fauna, and the Study of Consciousness. Victoria, TX: Self Published. 346.

Ya'u, J., Yaro, A. H., Abubakar, M. S., Anuka, J. A., and Hussaini, I. M. (2008). Anticonvulsant activity of Carissa edulis (Vahl) Apocynaceae) root bark extract. J. Ethnopharmacol. 120, 255-258. doi: 10.1016/j.jep.2008.08.029

Conflict of Interest Statement: The authors declare that the research was conducted in the absence of any commercial or financial relationships that could be construed as a potential conflict of interest.

Copyright (c) 2016 Khan, Khan and Ahmed. This is an open-access article distributed under the terms of the Creative Commons Attribution License (CC BY). The use, distribution or reproduction in other forums is permitted, provided the original author(s) or licensor are credited and that the original publication in this journal is cited, in accordance with accepted academic practice. No use, distribution or reproduction is permitted which does not comply with these terms. 